\title{
Civil litigation Procedure - a New Code of Procedure of the Slovak Republic
}

\author{
Svetlana Ficová \\ Comenius University in Bratislava, Faculty of Law, Slovakia \\ svetlana.ficova@flaw.uniba.sk
}

FICOVÁ, Svetlana. Civil Litigation Procedure - a New Code of Procedure of the Slovak Republic. International and Comparative Law Review, 2016, vol. 16, no. 1, pp. 23-37. DOI: 10.1515/iclr-2016-0002.

\begin{abstract}
Summary: On 1 July 2016 the new codes of civil procedure will come into effect with the aim to provide for more effective, simplified and more economically efficient civil procedure, including more efficient enforcement of law in Slovakia. This article explains some of the new legal concepts that may facilitate attainment of this goal.

Keywords: Re-codification in the Slovak Republik, Civil Litigation Code, intervenient/ intervener, litis denuntiatio (notice of suit), service of process, claim/court action, judicial concentration, preliminary hearing, default judgment, illegal evidence, court costs, protection of contractually weaker party, appeal, appellate review sought by the General Prosecutor.
\end{abstract}

\section{Introduction}

Effective of 1 July 2016, the three new codes of civil procedure will replace the current Code of Civil Procedure, Act 99/1963 Zb ${ }^{1}$, namely Civilný sporový poriadok/Civil Litigation Code, Civilný mimosporový poriadok/Civil NonLitigation Code and Správny súdny poriadok/Code of Administrative (Court) Procedure.

The legislator has thus decided to enact separate codes for contentious matters, non-contentious matters and the matters falling under administrative justice.

At the time of interdepartmental consultations various views ${ }^{2}$ appeared not approving this decision of the re-codification commission. But these views and comments were not accepted by the re-codification commission. For taking a stand whether the enactment divided into the three codes was proper or practi-

1 Amended on 88 occasions, up to this date.

2 Fore more detail see ŠTEVČEK, Marek. Princípy a východiská nových kódexov civilného procesu. O dogmách, paradigmách a trochu o právnej filozofii /Principles and starting points of the new codes of civil procedure. On dogmas paradigms and a little bit of legal philosophy/. Bulletin slovenskej advokácie, 2014, vol. 20, no. 12, p. 15-17. 
cal, in particular, it may be necessary to consider above all to what the extent the three codes differ one from the other, to what extent they contain concurrent rules, and to what extent they refer one to the other. This, however, is beyond the intent of this article. Without making any complimentary or criticizing statements in this discussion, the situation of the three separate codes is accepted as it exists. In my opinion, there would not be much difference between the enactment contained in one single code and the one divided into separate codes by their subject-matter. Its legal taxonomy and the rules concerning the relevant concepts are much more important.

With regard to the breadth of the enactment my article deals solely with the Civil Litigation Procedure Code. But this does not indicate at all that this Code is more important than the two other codes. However, this Code may be prioritized, to some degree, because both the Civil Non-Litigation Procedure Code and the Code of Administrative Court Procedure refer secondarily to the Civil Litigation Procedure Code ( $\$ 2(1)$ of the Civil Non-Litigation Procedure Code and $₫ 5$ (1) and $₫ 25$ (1) of the Code of Administrative Court Procedure).

\section{Taxonomy/System of Classification of the Civil Litigation Procedure Code}

When compared to the system of classification contained in the current Code of Civil Procedure, no big changes may be expected in the taxonomy/classification of the Civil Litigation Procedure Code, as it is logically based on the progress of the judicial process. The only exceptions apply to some parts of the current Code of Civil Procedure that are now statutorily laid down in a new code. This applies to the following:

- Part Three, Chapter Five covering special provisions (in non-contentious matter), now transferred to the new Civil Non-Litigation Procedure Code,

- Part Five concerning administrative justice the rules of which are transferred to the Code of Administrative Court Procedure, and

- Part Six relating to enforcement/execution of judgments, the provisions governing the enforcement of judgment in cases of custody of minor children, transferred to the Civil Non-Litigation Procedure Code. The remaining parts applying to enforcement of judgment of debt payments claimed by the court and recovered by the Judicial Treasury, as provided by Act 65/2001 Z. z. on the administration and recovery of debt payments claimed by the courts, are newly provided for in this Act.

From among the changes in the system of classification, also Part Two of the Code of Civil Procedure concerning pre-trial court activities was left out in full. In future, no provisions will be made for conciliation proceedings originally included in Part Two of the Code of Civil Procedure. The rules of another pre- 
liminary activity - paternity determination by joint consensual declaration of parents - has been transferred to the Civil Non-Litigation Procedure Code ( $\$$ 104). And the last two concepts originally included in Part Two of the Code of Civil Procedure - interim measures (newly defined as immediate measures) and securing evidence - are newly regulated by the Civil Litigation Procedure Code, included, however, in Part Three, among special procedural rules.

Also Part Seven of the Code of Civil Procedure - other court activities - has been left out in full, as justified by the fact that such concepts do not necessarily have to be included in a procedure code ${ }^{3}$.

Newly incorporated in the taxonomy of the Civil Litigation Procedure Code are the articles (altogether 18) preceding the text arranged into sections, laying down the fundamental principles of this legislative enactment, and setting the framework of interpretation not only for the rules of the Civil Litigation Procedure Code, but, also the rules of the Civil Non-Litigation Procedure Code and the Code of Administrative Court Procedure. ${ }^{4}$

The Civil Litigation Procedure Code is divided into five Parts.

Part One, as previously, contains the general provisions, covering the subject-matter of the law (Chapter One), powers of the courts and their jurisdiction (Chapter Two and Chapter Three), composition of the courts and exclusion of judges (Chapter Four), parties to the proceedings, representation, and other/ specific legal parties to the proceedings (Chapter Five and Chapter Six), trial procedures, and time limits (Chapter Seven and Chapter Eight).

Part Two covers first-instance proceedings, since the provisions formerly regulating pre-trial procedures have been either left out in full or transferred to another part of the code or to another law (see the information above). In the framework of the first-instance proceedings, the original concepts and terms are preserved, such as procedures after commencement of the proceedings (Chapter One), the trial (Chapter Three), the evidence (Chapter Four), judicial decisions (Chapter Five) - with only judgment and resolution, and costs of the proceedings (Chapter Six), being partially modified. Newly included is the preliminary hearing (\$168-172) and complaint ( $\$ 239-250)$.

Part Three, as indicated also by its heading Special Procedures in Civil Process, is completely new. Although, not as far as its content as a whole. Some concepts/terms contained there come from the former enactment, some are completely new.

Taken from the previous code are e.g. the decisions resulting from the summary proceedings, namely, an order for payment and a European order for pay-

3 Explanatory Report, A. General Part.

4 Explanatory Report to the Civil Litigation Procedure Code, B. Special Part, text concerning Article 1. 
ment. The legislator has not incorporated any provisions concerning specific performance orders, or orders for payment of checks and bills of exchange for future use. Judgments based upon the party's conduct, i. e. judgments made upon admitted claims or judgments made upon waiver of the claim, as well as default judgments, have all been taken from the previous code. Among the new provisions, default judgment against defaulting claimant is now included.

Regulation of the concept of interim/provisional measures/orders, now called peremptory measures/orders in urgent cases have also been preserved. But additionally a new concept of safeguarding measures $(\$ 343-344)$ is defined. From among the original concepts, also that of securing the evidence has been preserved.

New concepts include proceedings for the protection of contractually weaker party. The legislator has created three basic forms - consumer disputes, (unfair) discrimination disputes and employment discrimination disputes.

Part Four remains reserved for appellate remedies. With reference to Article 6 of the Convention for the Protection of Human Rights and Fundamental Freedoms, the European Court the European Court of Human Rights case law ${ }^{5}$, the category of extraordinary appellate remedy has been left out. A new remedy - appellate review brought by the General Prosecutor $(\$ 458-465)$ has been introduced.

The last, Part Five, contains the conventional common, transitional and final provisions.

In this paper I am not concerned with Articles 1-18. ${ }^{6}$

\section{On some concepts included in the Civil Litigation Procedure Code}

The incorporation of the concept of the so called causal jurisdiction of the court in the Civil Litigation Procedure Code $(\$ 22-\$ 30)$ is a positive point. At present this concept is laid down in a special law, Act 371/2004 Z. z. on the addresses and districts of courts in the Slovak Republic, which is not an expedient solution.

Regrettably, the provisions on causal jurisdiction are not included right after the provisions governing the subject-matter jurisdiction of the courts; it would be a more systematic placement than placing them subsequent to the provisions on local jurisdiction of the courts. Therefore, it may seem at first sight that the interpretation problems about whether causal jurisdiction is a special/specific

5 Explanatory Report concerning the Civil Litigation Procedure Code, A. General Part.

6 I discussed Articles 1-18 of the Civil Litigation Procedure Code in my paper presented at the conference in May 2015, organized under the topic Principles of Civil Procedure by the Faculty of Law of Palacky University in Olomouc, published in Acta Iuridica Olomucensia, 2015, vol. 10, no. 1, p. 37-56. 
type of subject-matter or of local jurisdiction ${ }^{7}$ will continue, to which another problem was related, namely what a court ought to do when thinking no causal jurisdiction arises. However, it will be irrelevant in future as to how the concept of causal jurisdiction should be perceived. It is important that under $\$ 40$ of the Civil Litigation Procedure Code the court is required to inquire ex officio whether its causal jurisdiction exists, that is also in absence of any objections, and throughout the entire process.

The legislator abandoned the present concept of enjoined party/subsidiary party/co-party, replacing it by the concept of intervenient/intervener, as newly defined in $₫ 81-\S 88$ of the Civil Litigation Procedure Code.

What has remained unchanged is the condition that such party must a legal interest in the litigation results ( $\$ 81$ of the Civil Litigation Procedure Code). The intervenient may join the proceedings also on his/her own accord or upon a notice by either party to the dispute at any stage of litigation ( $\$ 82(1)$ and (2) of the Civil Litigation Procedure Code). Such intervenient may join either with the claimant or the defendant ( $\$ 81$ of the Civil Litigation Procedure Code). The court has no discretion to decide on such intervention in the litigation process, except where either party may request it ( $\$ 83$ of the Civil Litigation Procedure Code).

\section{What is different in the new Code?}

Two types of intervenient/intervener are introduced, together with a litis denuntiatio (notice of suit).

The first intervenient type is defined in $\$ 84$ of the Civil Litigation Procedure Code. Within its meaning the intervenient may form a necessary/indispensable union with the party, and where it is so set in a special law, the judgment is binding also for the intervenient.

A marginal note may be made at this point concerning inexpedient terminological wording of the provision according to which „... the intervenient creates, together with the party on whose side the intervenient acts ..." The party is a new term, replacing the term of a participant currently in use. This is not just a denomination referring to claimant or defendant. Translated into the present terminology this clause would read: „... the intervenient creates, together with the participant/party to the proceedings in which the intervenient acts ....". Therefore de lege ferenda it would be more appropriate to reformulate this text for example as follows: „...the intervenient creates, together with the party beside which he acts ..."

7 See different views presented in ŠTEVČEK, Marek. K problematike tzv. kauzálnej príslušnosti niektorých slovenských súdov /On the issues of the so called causal jurisdiction of some Slovak courts/. Justičná revue, 2009, vol. 61, no. 6-7, p. 852-860; FICOVÁ, Svetlana. Otázniky nad kauzálnou príslušnostou /Question marks over causal jurisdiction/. Justičná revue, 2009, vol. 61, no. 6-7, p. 861-867. 
These provisions present still another terminological inaccuracy. These two different concepts/terms" are combined in one legal party, the intervenient with the necessary/indispensable union. It is not possible for a dominus litis to act as a necessary/indispensable party, and also as an intervenient (subsidiary party/ co-party). In one and the same litigation such party may either be a dominus litis/ main party or an intervenient.

The legislator's intent is quite obvious. However, more appropriate terminology might have been used, such as e.g. „in such cases, as for the position of an intervenient, the rules governing the necessary/indispensable union are applicable“.

And now, the very nature of this type of intervenient may be discussed.

For the rules governing the necessary/indispensable union to be applicable for the intervenient, the following two conditions must be met concurrently:

- Judgment is binding for the intervenient, and

- this binding obligation arises from a special law.

In the Explanatory Report this is illustrated by reference to provisions of $\$$ 54 (2) of the Commercial Code ${ }^{8}$ or $\$ 131$ (5) of the Commercial Code. On the same basis, also provisions of $\$ 369 \mathrm{~d}(6)$ of the Commercial Code are construed.

Where the intervenient fails to satisfy the two conditions of law, the provisions governing necessary/indispensable union of parties, should not be applicable for the intervenient. These cases correspond with the other type of intervenient.

Distinguishing between the two types of intervenient has important impact on independent conduct of such parties. Where the rules governing the necessary/indispensable union do apply, the intervenient may, on his/her own accord, use the procedural means of attack or defense without any approval of the main party ( $\$ 84$ in conjunction with $\$ 77$ of the Civil Litigation Procedure Code). The procedural means of attack or defense defined in the Civil Litigation Procedure Code include, in particular, allegations of fact, denial of the facts alleged by the opposing party, proposed evidence, objections to the evidence proposed by the opposing party, and objections based on substantive law ( $\$ 149$ of the Civil Litigation Procedure Code). Under the same conditions, i.e. without consent of the main party, the intervenient may seek an appellate remedy [appeal ( $\$ 360$ (1) of

8 The entitled persons whose rights have been impaired or endangered by unfair competition may, through a court action commenced to restrain a wrongful conduct, demand that the wrongdoer abstain from such conduct and remedy the detrimental/objectionable conditions. No court actions brought by any other entitled persons seeking the same claims in the same proceedings are admissible, but the entitled persons may join the proceedings as subsidiary parties. Final judgments in these claims of one entitled person are effectively applicable also to other entitled persons. 
the Civil Litigation Procedure Code), re-trial ( $\$ 401$ of the Civil Litigation Procedure Code), or appellate review ( $\$ 425$ of the Civil Litigation Procedure Code)].

Where the rules governing necessary/indispensable union do not apply, the intervener's rights to use the procedural rules of attack or defense will be limited, as these rights may be exercised only with the consent of the party beside which the intervenient acts in the proceedings ( $\$ 85$ of the Civil Litigation Procedure Code). Such intervenient also needs such consent when filling an appeal ( $\$ 360$ (2) of the Civil Litigation Procedure Code). And such intervenient has no right to seek a re-trial/renewal of the proceedings or appellate review at all, that is, regardless of whether the party to the proceedings was willing to grant such consent.

The conditions necessary to be met as for the provisions governing necessary/indispensable party to be applicable for the intervenient will be, unquestionably, subject to a detailed interpretation analysis; especially the definition element "... where the binding nature of judgment arises from a special law." Should a narrow interpretation prevail, being limited only to cases expressly anticipated by a legal rule (as illustrated in the Explanatory Report in relation to $\$ 80$ of the Civil Litigation Procedure Code), and not to cases in which it follows from the merits of the dispute that the judgment dictum will affect the relationship between the intervenient and the party joined by intervenient, then it would not be possible to consider this a step forward. Since sufficient leeway for abuse of law still remains here, for example in cases of the insurance company's obligation to pay'.

The introduction of the concept/term of notice of suit (litis denuntiatio) may be assessed as constructive, together with the related effects depending on whether the intervenient will join the proceedings or not ( $\$ 86-\$ 88$ of the Civil Litigation Procedure Code). In both cases, where the dispute has been finally decided, it is not possible to object the decision is wrong. Also the option to object wrong procedural conduct is limited as it relates to expressly enumerated cases, only. The law has, however, failed to consider a situation, in which the party acting as dominus litis has not notified the intervenient about the suit/ litigation or has notified the intervenient, but not in the manner implied by $₫ 86$ of the Civil Litigation Procedure Code (stating what claims and their reasons may be sought against the intervenient by the main party when not successful in litigation).

9 A flagrant case publicized in Trend magazine 6/2004, in which The Slovak Insurance Association, was threatened with making payment from the mandatory contractual insurance of SKK 30 million as damages for pain and social hardship to the wife, without any right to seek appeal in absence of consent granted by the aggrieved person's husband as the principal party to the proceedings, may be found analyzed by GEŠKOVÁ, Katarína; ŠORL, Róbert: Postavenie a zmysel inštitútu vedlajšieho účastníka v civilnom procese a jeho vývojové premeny /The position and meaning of a subsidiary party in civil trials and its developing changes/. Justičná revue, 2005, vol. 57, no. 8-9, p. 1024. 
Under the present law, also a legal person/entity, the business activities of which include protection of rights under a special law, may act as a subsidiary party/co-party, even in absence of the legal interest in the results of litigation; under the Civil Litigation Procedure Code such co-party will act in the position of a specific party ( $\$ 95$ of the Civil Litigation Procedure Code). Surprisingly, the position of such person will be stronger than that of an intervenient to whom the rules governing the necessary/indispensable union do not apply. The position will be stronger since a legal entity, acting as a specific party to the proceedings, is entitled to exercise all acts in law applicable to a party (except for the acts in law exercisable by a party who is subject to substantive-law relations) without an express consent of a co-party. In case their acting is conflicting, the court will consider it so that it will correspond with a reasonable settlement of the relations involved ( $\$ 95$ (3) of the Civil Litigation Procedure Code). Unlike in case of a specific party to the proceedings, the intervenient, as already mentioned, may exercise the acts only with the consent of the co-party. If such consent has not been granted, the court may not take into regard the intervener's procedural conduct and may not consider the issue as to what would correspond with a reasonable settlement of the relations involved.

Significant changes have affected the concept of service of process $(\$ 105-\S$ 116 of the Civil Litigation Procedure Code) due to substantial simplification. The simplification results from preference of service at an electronic mailbox or, otherwise, service at a registered address.

In case of individuals/natural persons, service is at their address registered in the Register of Inhabitants of the Slovak Republic, or in case of an alien, at the address of residence in the Slovak Republic. The address registered in the Register of Inhabitants may be that of permanent or temporary residence and the citizen's address of residence abroad (as laid down by Act 253/1998 Z. z. on residence reporting residence by the citizens of the Slovak Republic and on the Register of Inhabitants of the Slovak Republic.

As for legal entities, service is at the address of their registered office as registered in the Companies Register, or another register.

Where the process documents cannot be served in this manner, legal fiction of service as of the date of documents returned to the court will apply. If the addressee does not dwell at the particular address for excusable reasons while not violating any legal obligation, the concept of legal excuse for missing the time limit will apply where, in the meantime, the time limit set for the service of process has expired.

The natural persons and legal entities are still free to give another address for the purpose of service of process or they may appoint a proxy for receiving the service of process documents. 
The law anticipates also a situation in which a natural person has no address registered in the Register of Inhabitants of the Slovak Republic. By legal fiction a document is deemed to have been served after 15 days following its publication at the official notice board and at the website of the relevant court.

The procedure for serving the initial legal action/claim on a natural person, compared to other types of legal documents, is slightly stricter. If such notice to the defendant who is a natural person cannot be served at the address registered in the Register of Inhabitants of the Slovak Republic or at the alien's address of residence in the Slovak Republic, the court cannot serve the notice of legal action immediately by publication at its official notice board or the website. First the court takes all steps necessary to ascertain the actual location of the defendant $(\$$ 116 of the Civil Litigation Procedure Code).

The law has introduced a new concept/term of manifestly unfounded claim/ initial legal action ( $\$ 138$ of the Civil Litigation Procedure Code). In such case the court should demand the claimant to withdraw the claim/initial legal action. How the court should proceed in case that the claimant fails to do so is not included in the provision quoted above. Should the court continue in the proceedings and take evidence in order to make a decision on the merits, or should the court apply the provisions of Article 5 of the Civil Litigation Procedure Code containing the fundamental rule of interpretation? Under this Article the court could dismiss the claim/initial legal action as a procedural act in law and use sanctions. Some uncertainty concerning such interpretation has been caused by changes brought in the wording of the Civil Litigation Procedure Code when compared to its draft presented for interdepartmental consultations. Article 4 of the draft included not only denial of procedural acts in law, but also dismissal of such legal action. The Explanatory Report does not explain this modification, either. So it is not clear whether leaving out the word "initial legal action/claim" from the original Article 4, now Article 5, by reasons of redundancy, as the initial legal action is one of procedural acts in law, or on the grounds that dismissal and sanctioning do not apply to initial legal actions even though they may be manifestly unfounded.

In $\$ 149$ of the Civil Litigation Procedure Code a new term/concept procedural means of attack and defense has been introduced, containing, however, just demonstrative enumeration. Included are, in particular, allegations of fact, denial of facts alleged by the opposing party, proposed evidence, objections to the evidence proposed by the opposing party, and objections based on substantive law. In the interest of speed and economic efficiency, the law requires their timely application/exercise under threat of a sanction that otherwise the court may disregard them. Thus, also the concept of judicial concentration of/setting strict time limits for the process ( $\$ 153$ of the Civil Litigation Procedure Code) is laid down. This is most clearly applied in the procedures following the service of the initial court action/claim upon the defendant $(\$ 167)$. The defendant must 
answer within the time limit set by the court and indicate his/her defense evidence. The defendant's answer is sent by the court to the claimant who, again, must reply to the statements concerning the defendant's answer and evidence. Where the claimant makes a replication, the court must (unless the court makes another relevant order) serve it on the defendant so that the defendant may respond (make a rejoinder). When will this process end should the parties make new statements of fact indicating also new evidence in response to the opposing party's response? The law is silent on a further procedure in $₫ 167$ of the Civil Litigation Procedure Code. Does it mean that the second response by the defendant/rejoinder will not be sent by the court to the claimant for his/her response/surrejoinder? No unambiguous answer to this question can be found in the fundamental interpretation rule laid down in Article 9 of the Civil Litigation Procedure Code, either. Within its meaning the parties to the dispute have the right to be informed of the opponent's responses, proposals and evidence, and to present their own views. According to Article 9, the court could be sending the information for the opposing party until one of the parties can provide no new allegations of fact or indicate proposed evidence. However, Article 9 contains an additional idea, according to which the parties have the right to be informed and to respond within the scope set by law. Does it mean that the rules contained in $\$ 167$ of the Civil Litigation Procedure Code are limited to service of initial legal action/ claim upon the defendant, service of defendant's answer upon the claimant, and the last service of claimant's reply/replication upon the defendant should be considered the scope set by law within which the responses of one party to the other end?

In addition to the judicial concentration/setting strict time limits, the existing legal concentration of the process is preserved, according to which the procedural means of attack and procedural means of defense may be used before a resolution on completion of taking of the evidence.

The next novelty is preliminary hearing $(\$ 168-\S 172$ of the Civil Litigation Procedure Code). It may be considered a replacement of the present preparation for trial/hearing. This is not an obligatory part of the proceedings. Preliminary hearing takes place before the first trial hearing, unless the court has determined otherwise. Within preliminary hearing the court should try to reach settlement by conciliation of the parties. If not successful, the court should determine which allegations of fact are at issue, which have been admitted, which evidence will be taken and which evidence will not be taken, announcing also its preliminary legal observations and the anticipated date of trial. The law gives the court the right to make a decision on the merits of the case already at this stage of the process, generally depending on whether it is feasible and/or reasonable. Both claimant and defendant must be present at the preliminary hearing of the case. Actually, the court has a discretion (not an obligation) to make a default judgment against the party absent without a good cause, provided the party has been 
duly and timely summoned and instructed on such judicial discretion, and provided also the repeated procedure of service of process documents upon both parties, as described above in reference to $\$ 167$ the Civil Litigation Procedure Code. Thus, a leeway has been newly provided for making a default judgment also against the claimant, not only against the defendant, as it is at present.

A judgment in case of default by claimant is possible also under $\$ 273$, et seq. of the Civil Litigation Procedure Code. The rules for such judgment are the same as in the case of the defendant's default (failure to appear to a hearing despite his/ her timely and duly summoning, failure to excuse his/her absence in due time, good cause announced upon serious circumstances, and the instruction on possible default judgment). By a default judgment against the defendant, the legal action is dismissed.

Within the framework of taking of the evidence, the provision contained in $\$ 187$ (1) of the Civil Litigation Procedure Code is worth mentioning. According to this provision, everything obtained in a lawful manner through the means of evidence may serve as a proof. Based on such wording it may appear that also illegal (means of) evidence may be used in civil litigation. It is only illegal proof that may not be used, i.e. the information ${ }^{10}$, resulting from the evidence adduced. In other words, when the evidence, although illegally obtained, is adduced in accordance with the law, the resulting proof (the information) is lawful and may be used in weighing the evidence. However, if the evidence, although lawfully obtained, is adduced in violation of law, such proof (information) is illegal, and must be excluded from weighing the evidence. However, the interpretation is not as simple as it may appear. Actually, we may say it is disallowed under Article 16 (2) of the Civil Litigation Procedure Code. Within its meaning, in considering and deciding the matters of the case, the court does not take into regard the evidence obtained unlawfully/contrary to law, unless the presentation of the evidence obtained unlawfully may be justified under Article 3 (1) of the Civil Litigation Procedure Code. Although in the Explanatory Report the bill presenter maintained, in reference to $\$ 183$ that the terms "proof" and "(means of) evidence" are thoroughly distinguished, in fact the opposite is true. A proof is mentioned in relation to its presentation. But a proof is just the information obtained by presenting (the means) of evidence. Thus, it is the evidence which is presented, not the proofs. By such terminological modification, this Article would read (in abridged wording as for its substance) ,....does not take into regard the proofs obtained contrary to law, unless presentation of the (means of) evidence obtained unlawfully may be justified under Article 3 (1) of the Civil Litigation Procedure Code". Thus we come to the meaning other than that implied by $\$$ 187 (1). Under Article 16 (2) of the Civil Litigation Procedure Code, in principle unlawfully obtained evidence may not be used. The only exception is the

10 As for the definition of the concept of proof, see e.g. WINTEROVÁ, Alena et al: Civilní právo procesní /Civil Procedural Law/. Praha: Linde, 1999, p. $216 .$. 
situation, where the presentation of the evidence is justified (e.g. because the right to have personal rights protected where the statements of a person have been recorded without his/her consent, is, in this particular case, proportionally weaker when compared to a constitutional right the violation of which is to be proven by the evidence so obtained; proportionally stronger is the right to racial, gender or other nondiscrimination) ${ }^{11}$.

The next novelty is complaint/statement of discontent $(\$ 239-\$ 250$ of the Civil Litigation Procedure Code). It may be made only against a first-instance resolution, never against the judgment. Concurrently a condition requiring the resolution to be issued by a judicial officer must be satisfied. Such complaint is not included among appellate remedies. According to the Explanatory Report referring to $\$ 233$, this is a remedial procedure of the defense. However, it comprises all the elements of an appellate remedy - subjective and objective conditions of admissibility, suspending effect and determination of whether it may be granted or denied.

Simplification of court costs $(\$ 251-\$ 264)$ is certainly to be welcomed, because they were made more and more complicated by each of the amendments to the current Code of Civil Procedure until reaching the present unhappy situation. This enactment contains no classification of various types of court costs/ costs of proceedings by means of illustrative enumeration. The court costs/costs of the proceedings are specified merely by general signs of provability, reasonableness, purposefulness, and limitation to the commencement of the proceeding. The principles of payment of court costs, reimbursement of court costs, and of exemption of court fees have remained almost unchanged. A considerable change concerns determination on the court costs. Once again we have returned to the court's obligation ex officio to determine on the court costs, i.e. not only at the party's request. However, the court will only decide on the right to reimbursement of the court costs, not on their amount. The court will only decide which of the parties has the right to reimbursement of the court costs and in what proportion (in the form of a fraction or percentage). The court determines on the right to reimbursement of the court costs in the decision by which the proceedings are closed. Only after the decision becomes final, the amount of court costs will be set. This will always be determined by the first instance court, i. e. also where the proceedings are closed by a decision of the court remedying an error. The decision (resolution) of the amount of court costs is now to be issued by a judicial official in order to unburden the judges. Such resolution may be challenged by a complaint under $\$ 239$, et seq. upon decision of a first-instance court.

A new kind of proceedings is being introduced with the aim to provide for judicial protection of contractually weaker party. This applies to consumer disputes, antidiscrimination disputes and labor disputes of individuals. What is the basis of higher protection provided by the court? In the first place this

11 Special part of the Explanatory Report concerning Article 16 
applies to widening the general duty to instruct the weaker party, i. e. a consumer, a person in relation to whom the principles of equal treatment were violated, and an employee. Under this special duty to instruct beyond the scope of the general duty, the court must inform these persons, already during the first act in law, on the options of legal representation, on the evidence that must be presented, on the options to request immediate, and security measures, or other alternatives that may be reasonably used in exercising and defending the rights of such persons. In proving the facts the court is not limited to the evidence proposed by the parties. The court may obtain and present the evidence not proposed by the weaker party. Thus, the principle of inquiry, unilaterally applied in relation to finding and proving the facts concerning the weaker party is anticipated. Similarly, the provisions governing judicial and legal concentration of the process do not apply, once again only unilaterally. By the same unilateral application, the possibility to make a default judgment against the weaker party is excluded.

Quite a minor change concerns the system of appellate remedies. Instead of extraordinary appellate review, the appellate review lodged by the General Prosecutor is laid down. The other appellate remedies have been sustained.

As for appeals ( $\$ 355-\$ 396$ of the Civil Litigation Procedure Code) the rules of admissibility of appeal against a resolution have been changed, so an appeal is possible only against resolutions concerning exhaustively enumerated cases. Where a complaint is admissible against such resolution, an appeal is excluded. As for the grounds for appeal, changes may be found merely in the reformulated wording, the essence of grounds remain unaffected. The change relates to summary judgments (based on admission or waiver of claim, and default judgment). Such judgments may be appealed on the grounds that the conditions for issuing the judgment have not been met. That means not also by reason of incorrect legal consideration of the case. The effort to prevent "blank" appeals, the appeals giving no reasons of appeal, may be positively accepted. Some normative attempts in this area were made also in the past, but without any desirable effects. As a result, the Supreme Court ruled $^{12}$ that where the appellant failed to state any grounds of his/her appeal, the Court must try to remedy such deficiency. If the appeal was amended, also beyond the time limit set for appeal but before the decision made by the appellate court, the Court must consider and review such appeal as faultless. The legislator, having taken lesson from this interpretation by the Supreme Court, has expressly stipulated that the court will not ask the appellant to submit the missing reasons for appeal $(\$ 373$ (1) of the Civil Litigation Procedure Code). In conjunction with $\$ 365$ (3) of the Civil Litigation Procedure Code this means that reasons for appeal may be modified and amended only within the time limit set for appeal, not later. Surprisingly the same limitation is

12 Published in the Collections of Opinions of the Supreme Court of the Slovak Republic and Judgments of the Courts of the Slovak Republic under R 20/2014, case no. 1 Cdo 195/2005, of November 22, 2005. 
stipulated also in relation to the means of evidence and also in the new concepts. The appellant's respondent is limited, as for the means of defense or attack, by the time limit set by the court for responding to the appeal which may not be less than ten days ( $\$ 373$ (3) and (4) of the Civil Litigation Procedure Code).

In place of extraordinary appellate review, a new appellate remedy, appellate review sought by the General Prosecutor $(\$ 458-\S 465$ of the Civil Litigation Procedure Code) has been laid down. But it may be seen as a correction of the present extraordinary appellate review. The correction concerns the extension of admissible subject-matters. Appellate review by the General Prosecutor is admissible against any final judgment (subject to further conditions that must be satisfied), irrespective of the subject-matter of dispute, the amount in dispute, the form or method of the decision, except for a decision made upon appellate review or a decision made upon appellate review brought by the General Prosecutor which may not be challenged by an appellate review sought by the General Prosecutor ( $\$ 459)$. The time limit for appellate review sought by the General Prosecutor has been reduced to three months. The reasons, representing, concurrently, the conditions of admissibility, have been reduced to two - the decision has been made in violation of the right to a fair and just trial, and the conclusions in matters of law which are arbitrary or unsustainable. Simultaneously, the need to set aside/quash a decision/judgment must prevail over the interest to sustain it as irrevocable, and/or over the principle of legal certainty. The option to suspend enforcement of judgment ex lege by seeking an appellate review together with a request to suspend enforcement of judgment has been abandoned.

\section{Instead of a conclusion}

According to the Explanatory Report (its General Part) these legal measures represent fundamental and unavoidable steps taken to improve enforceability of law in the Slovak Republic, and to reach more effective and speedy judicial decisions. The fundamental aim of the re-codification is to make civil procedure more effective and economically more efficient, to accelerate and streamline the civil process, and thus to provide for a more efficient protection of rights and legitimate interests of individuals and legal entities, and of the interests of the whole society.

Whether this aim will be reached and fulfilled, will be the matter of everyday practice and application.

It would be too naïve to believe the law will be interpreted without any problems. Similarly naive it would be to expect that the parties or their legal representatives will not take advantage of legislative holes, or at least to make obstructions in an effort to prolong the proceedings and thus to delay the anticipated unfavorable decision. Such has always been the true reality, and it will be so in future, too. Still we must hope that a legal doctrine that needs to amplify its activ- 
ICLR, 2016, Vol. 16, No. 1.

ity, will contribute, at least to some extent, to bring, in particular, more uniformity in the interpretation of some of the legal norms.

The task of the science and theory of law is not just to criticize the existing legislation and decisions made by the courts. Its task is to provide explanations, trying, on the basis of logical arguments, to help the judicial practice also by reference to some legal deficiencies, ideally by presenting some de lege ferenda proposals. 